Article

\title{
Agricultural LCA for Food Oil of Winter Rapeseed, Sunflower, and Hemp, Based on Czech Standard Cultivation Practices
}

\author{
Jaroslav Bernas ${ }^{1, *(D)}$, Tereza Bernasová ${ }^{2}$, Václav Nedbal ${ }^{2}$ and Reinhard W. Neugschwandtner ${ }^{3} \mathbb{D}$ \\ 1 Department of Agroecosystems, Faculty of Agriculture, University of South Bohemia, Studentska 1668, \\ 37005 Ceske Budejovice, Czech Republic \\ 2 Department of Applied Ecology, Faculty of Agriculture, University of South Bohemia, Studentska 1668, \\ 37005 Ceske Budejovice, Czech Republic; veselt04@zf.jcu.cz (T.B.); nedbav00@zf.jcu.cz (V.N.) \\ 3 Department of Crop Sciences, Institute of Agronomy, University of Natural Resources and Life Sciences \\ Vienna (BOKU), 3430 Tulln, Austria; reinhard.neugschwandtner@boku.ac.at \\ * Correspondence: bernas@zf.jcu.cz
}

Citation: Bernas, J.; Bernasová, T.; Nedbal, V.; Neugschwandtner, R.W. Agricultural LCA for Food Oil of Winter Rapeseed, Sunflower, and Hemp, Based on Czech Standard Cultivation Practices. Agronomy 2021, 11, 2301. https://doi.org/10.3390/ agronomy11112301

Received: 21 October 2021

Accepted: 11 November 2021

Published: 13 November 2021

Publisher's Note: MDPI stays neutral with regard to jurisdictional claims in published maps and institutional affiliations.

Copyright: () 2021 by the authors. Licensee MDPI, Basel, Switzerland. This article is an open access article distributed under the terms and conditions of the Creative Commons Attribution (CC BY) license (https:// creativecommons.org/licenses/by/ $4.0 /)$.

\begin{abstract}
The demand for food vegetable oil is rising and this trend is reflected in the agricultural sector of the Czech Republic. The traditional oil crops of the Czech Republic are winter rapeseed and sunflower. These oil crops have high demands on energy inputs, for example, in the form of land preparation and chemical protection. At the same time, they are characterized by high food oil production and oiliness. Moreover, marginal oils crops, such as hemp, are also gaining prominence. This work aimed to evaluate the environmental impacts associated with the cultivation of winter rapeseed and sunflowers based on standard cultivation practices typical of the conditions of the Czech Republic. For comparison, an intensive cultivation strategy for hemp was modelled, also corresponding to the conditions of the Czech Republic. This study assessed the environmental impact of traditional oil crops from the agricultural Life Cycle Assessment (LCA) perspective. The system boundaries included all the processes from the cradle to the farm gate. Mass-based (volume of food oil) and area-based (land demand for generating the same volume of food oil) functional units were employed. The results cover nine impact categories related to the agricultural LCA. ReCiPe Midpoint $(\mathrm{H})$ characterization and normalization models were used for the data expression. Hemp is a plant with generally low demands on the inputs of the growing cycle but generally has a low oil production, which affects the character of the results relating to the goal and scope definition of the study. Hemp food oil thus generated a higher environmental impact per unit of production and area compared to sunflower and rapeseed food oil.
\end{abstract}

Keywords: agricultural LCA; vegetable food oil; hemp; winter rapeseed; sunflower

\section{Introduction}

The food sector is one of the major consumers of food oil, and the demand for food vegetable oil has been increasing for a long time [1]. The world's most cultivated oil crops have long been soybeans, rapeseed, cottonseed, peanuts, sunflowers, palm kernels, and coconuts. European vegetable oil consumption is based mainly on rapeseed, palm oil, soybeans, and sunflowers [2]. In the Czech Republic, winter rapeseed, poppy, sunflower, soybean, mustard, and linseed have traditionally had the highest share in the area under oil crops [3]. The Czech Republic has 2,958,603 ha of arable land; winter rapeseed was grown on approximately 380,000 ha $(12.5 \%)$ and sunflowers on about 15,000 ha $(0.5 \%)$ in recent years [2]. Nearly half of winter rapeseed oil production is for food purposes. Hemp, which has good potential in food oil production [4,5], is also beginning to appear increasingly (at about 600 ha) on arable land in the Czech Republic [3].

All agricultural activity is more or less linked to the impact on the environment [6]. The intensity of these impacts is also related to the intensity of agricultural production itself. In particular, oil crops, such as rapeseed, are among the crops that generally have 
high demands in terms of treatment and care [7]. These demands are then reflected in the impacts on the environment and its individual components [8,9]. Sustainable development, sustainable production, and consumption in the agri-food sector are key issues stimulating the creation of many international activities and strategies to reduce environmental impacts and seek sustainable production routes [10]. Due to the wide range of possible impacts on the environment and their diversity, it is not easy to evaluate the complex effects of the agricultural system with one method. There are various methods for assessing one or more indicators that determine the level of a particular impact. They can be quantified, for example, through the agricultural Life Cycle Assessment (LCA) method [11] and can thus point out possible options that could lead to the mitigation of these impacts [12].

Thanks to LCA, it is also possible to carry out a comparative study, which can help find a suitable alternative or point to new possibilities in general crop production and oil crops production. Agricultural LCA aims for a comprehensive assessment of the environmental profile of the product system and is one of the most holistically applicable methods. Agricultural LCA is the widely accepted methodology for assessing the potential environmental impacts of agri-food chains and agricultural production systems. It is an analytical method that assesses the environmental impacts of products, services, technologies and human products and organizations in general [13]. In recent years, the number of studies evaluating the impact of agricultural products using the LCA method has increased. Comparative studies are often used to compare the environmental sustainability of products from different agricultural production systems [12]. Before the implementation of a potential sustainable farming system, scientists and the decision-makers need sufficient information about the positives and negatives of the production system with regard to productivity and performance. The LCA method provides a suitable assessment tool that meets the requirement of a comprehensive assessment of the environmental impacts of different production systems [12]. These outputs can then help implement concepts that correspond to the strategies of the common agricultural policy (CAP) and the European Green Deal [14]. However, for the conditions of the Czech Republic, such a model based on an LCA of winter rapeseed oil (sunflower oil and hemp oil, also) has not yet been implemented, although winter rapeseed is one of the dominant crops on arable land. Whereas rapeseed cultivation can bring more biological diversity to the landscape, as reported for Sweden which has a share of rapeseed on arable land of about 4\% [15], the Czech Republic has a share of $14 \%$ - the highest in the EU [16].

This comparative LCA study aims to quantify the environmental impact associated with conventional winter rapeseed and sunflower food oil production, as the most widely represented oil crops in the Czech Republic, and to compare them with conventional hemp cultivation, which has in recent years gained great popularity in many agricultural sectors [17]. The attribution approach, the mass allocation principle, the characterization model, and the normalization model for data interpretation were chosen for this study. The functional unit related to the yield (volume of food oil yield) and the functional unit related to the area equivalent to the area needed to gain the same yield (volume of food oil) are used for data interpretation. This study reviews the environmental impact of rapeseed, sunflower, and hemp food oil production from the perspective of Czech standard cultivation practices. The results point to the impacts of individual inputs on the growing cycles and farming strategies, respectively, and allow for comparison of the two dominant oil crops (winter rapeseed and sunflower) and one minor alternative oil crop with the promised environmental potential. This paper will expand knowledge concerning winter rapeseed, sunflower, and hemp production with respect to environmental issues, and bring a new perspective to agronomy policy design.

\section{Materials and Methods}

\subsection{Goal and Scope Definition}

This study aims to quantify the environmental impacts of winter rapeseed oil, sunflower oil, and hemp oil by using the agricultural LCA. A functional unit (FU) related to 
production ( $1 \mathrm{~m}^{3}$ of food oil) and area unit (land demand for generating the same yield of food oil) was chosen for this study. The system boundaries include all the processes "from cradle to farm gate". Data geographically related to central Europe and the Czech Republic were used. As in a study based on agricultural LCA [18,19], agrotechnological operations were also incorporated into the model system: from pre-seeding preparation, through harvesting of the main product, to the transport of farming machinery, the production and use of crop-protecting agents, the production and use of fertilizers, the harvest, and transportation of the main product from the harvest site. Land-use changes were taken into account. Infrastructure processes were part of database inputs. Manure production and management have not been included. Cow manure was considered to be a residual product of the animal production systems, so emissions from the animal production system were not included. Emissions that occur from manure application were included in the processes where this occurs (e.g., the crop cultivation processes) [19]. Waste management was included in the form of compost. In the frame of this research, the transport distance from the farm to the field did not exceed $10 \mathrm{~km}$. A mass allocation principle approach (allocation based on significant characteristics of co-products; food oil, cake, and straw yield) was employed in this study. The results of this research may be used to motivate environmentally friendly farming systems and as a source of information on agricultural subjects that relate to farming practices (Bernas et al., 2021). The data were analyzed and evaluated by LCA standards [20,21].

\subsection{Data Source and Life Cycle Inventory (LCI)}

This study was based on the standards of agricultural practices related to the conditions of the Czech Republic [22] as the primary data source. Information on seed yield and straw yield were updated according to the Situation and Outlook Report on oil crops prepared by the Ministry of Agriculture of the Czech Republic [2,22]. Individual monocrops of selected oil crops were evaluated. Secondary data for background processes were taken from the Ecoinvent v3.7 [23], Agri-footprint v4.0 [24], and WFLDB [25] databases.

\subsection{Software Data Inventorization}

The cultivation approaches and fertilization intensity were set up according to standard intensive agricultural practices [22]. Data were related to the average conditions of the Czech Republic. Based on seed yield information [2,22], food oil yield level and cake yield level were determined. These data were used to determine the area needed for generating the same food oil yield. Information (input data) related to individual oil crops, the number and frequency of agrotechnical inputs, inputs from the technosphere, inputs from nature, information about emissions to water and air are included in the following table (Table 1). The mass allocation principle was set up according to outputs from the growing cycles of individual oil crops.

Table 1. Inventory table: inputs and outputs of the life cycle.

\begin{tabular}{lcccc}
\hline & Unit & Rapeseed & Sunflower & Hemp \\
\hline Outputs & & & & \\
\hline Seeds yield & $\mathrm{kg} \mathrm{ha}^{-1}$ & 3500 & 2800 & 500 \\
Straw yield & $\mathrm{kg} \mathrm{ha}^{-1}$ & 4200 & 7000 & 9000 \\
Cake yield & $\mathrm{kg} \mathrm{ha}^{-1}$ & 2206.4 & 1715.8 & 409.9 \\
Food oil & $\mathrm{L} \mathrm{ha}^{-1}$ & 1293.6 & 1084.2 & 190.2 \\
Seed oiliness & $\%$ & 42 & 44 & 36 \\
Cake oiliness & $\%$ & 12 & 12 & 12 \\
Land demand for generating the same yield \# & ha & 1 & 1.3 & 6.8 \\
Mass allocation principle (based on outputs) & & & & \\
\hline
\end{tabular}


Table 1. Cont.

\begin{tabular}{|c|c|c|c|c|}
\hline & Unit & Rapeseed & Sunflower & Hemp \\
\hline Food oil & $\%$ EL & 16.8 & 11.06 & 1.98 \\
\hline Cake & $\%$ & 28.65 & 17.51 & 4.27 \\
\hline Straw & $\%$ EL & 54.55 & 71.75 & 93.75 \\
\hline \multicolumn{5}{|l|}{ Inputs from technosphere-Material/fuels } \\
\hline Tillage, cultivating, chiselling & ha & 0.8 & 0.2 & 2 \\
\hline Tillage, rolling & ha & 0.3 & - & 2 \\
\hline Tillage, harrowing, by spring tine harrow & ha & 0.3 & 1.6 & - \\
\hline Tillage, harrowing, by offset levelling disc harrow & ha & - & 0.3 & - \\
\hline Tillage, harrowing, by offset disk harrow & ha & - & 1 & - \\
\hline Fertilizing, by broadcaster & ha & 1.45 & 1.1 & 0.87 \\
\hline Potassium chloride, as $\mathrm{K}_{2} \mathrm{O}$, at plant & $\mathrm{kg} \mathrm{ha}^{-1}$ & 15 & 9 & 9 \\
\hline \multirow{2}{*}{$\begin{array}{l}\text { Phosphoric acid, as } \mathrm{P}_{2} \mathrm{O}_{5} \text {, at plant } \\
\text { Ammonium nitrate phosphate (ANP), as } \mathrm{P}_{2} \mathrm{O}_{5} \text {, at } \\
\text { plant }\end{array}$} & $\mathrm{kg} \mathrm{ha}^{-1}$ & 23.03 & - & - \\
\hline & $\mathrm{kg} \mathrm{ha}^{-1}$ & - & 9 & - \\
\hline Triple superphosphate, as $\mathrm{P}_{2} \mathrm{O}_{5}$, at plant & $\mathrm{kg} \mathrm{ha}^{-1}$ & - & - & 19.75 \\
\hline Solid manure loading and spreading & $\mathrm{kg} \mathrm{ha}^{-1}$ & 12,000 & 10,000 & 4000 \\
\hline Manure, solid, cattle & $\mathrm{kg} \mathrm{ha}^{-1}$ & 12,000 & 10,000 & 4000 \\
\hline Tillage, ploughing & $\mathrm{kg} \mathrm{ha}^{-1}$ & 1 & 1 & 0.1 \\
\hline $\begin{array}{l}\text { Application of plant protection product by field } \\
\text { sprayer }\end{array}$ & $\mathrm{kg} \mathrm{ha}^{-1}$ & 5.9 & 4.9 & 1.4 \\
\hline Napropamide & $\mathrm{g} \mathrm{ha}^{-1}$ & 90 & - & - \\
\hline Herbicide, unspecified, mix for oil crops, at plant & $\mathrm{kg} \mathrm{ha}^{-1}$ & 2.29 & 3.65 & 2.45 \\
\hline Fungicide, unspecified, mix for oil crops, at plant & $\mathrm{kg} \mathrm{ha}^{-1}$ & - & 6.1 & - \\
\hline Sowing & ha & 1 & 1 & 1 \\
\hline Seeds & $\mathrm{kg} \mathrm{ha}^{-1}$ & 4 & 5 & 60 \\
\hline Chloroacetanilide herbicides, at plant & $\mathrm{g} \mathrm{ha}^{-1}$ & 372 & - & - \\
\hline Metaldehyde & g ha ${ }^{-1}$ & 40 & - & - \\
\hline Fluazifop-p-butyl, at plant & $\mathrm{g} \mathrm{ha}^{-1}$ & 75 & - & - \\
\hline Calcium ammonium nitrate (CAN), as $\mathrm{N}$, at plant & $\mathrm{kg} \mathrm{ha}^{-1}$ & 266.3 & - & 40 \\
\hline Nitrogen fertiliser, as $\mathrm{N}$ & $\mathrm{g} \mathrm{ha}^{-1}$ & 126 & - & - \\
\hline $\begin{array}{l}\text { Manure management, cattle, liquid-slurry, warm, per } \\
\text { kg DM }\end{array}$ & $\mathrm{kg}$ & 100 & - & 200 \\
\hline \multirow{2}{*}{ Slurry application, spreader with trailed hoses, per $\mathrm{m}^{3}$} & $\mathrm{~m}^{3} \mathrm{ha}^{-1}$ & 2 & - & 4 \\
\hline & $\mathrm{gha}^{-1}$ & 0.12 & - & - \\
\hline \multirow{4}{*}{$\begin{array}{l}\text { Dinitrophenol herbicides, at plant } \\
\text { Ammonium nitrate (AN), as N, at plant } \\
\text { Plant growth regulator, at plant } \\
\text { Urea ammonium nitrate (UAN) (with } 30 \% \mathrm{~N} \text { ), at plant } \\
\text { Magnesium oxide }\end{array}$} & $\mathrm{kg}$ & 60 & 70 & - \\
\hline & $\mathrm{g}$ & 0.37 & 0.2 & - \\
\hline & $\mathrm{kg} \mathrm{ha}^{-1}$ & 0.09 & 0 & - \\
\hline & $\mathrm{kg} \mathrm{ha}^{-1}$ & 0.03 & 3.5 & - \\
\hline Sulfur & $\mathrm{kg} \mathrm{ha}^{-1}$ & 0.024 & - & - \\
\hline Boric oxide & $\mathrm{kg} \mathrm{ha}^{-1}$ & 0.018 & - & - \\
\hline \multirow{2}{*}{ 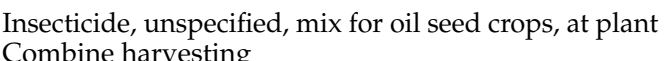 } & $\mathrm{kg} \mathrm{ha}^{-1}$ & 0.65 & 0.25 & 0.25 \\
\hline & ha & 1 & 1 & 1 \\
\hline \multirow{2}{*}{$\begin{array}{l}\text { Transport, tractor, and trailer, agricultural } \\
\text { Land-use change, annual crop, annualized on } 20 \text { years } \\
\text { Inputs from nature }\end{array}$} & $\mathrm{tkm}$ & 35 & 28 & 5 \\
\hline & ha & 1 & 1 & 1 \\
\hline \multirow{3}{*}{$\begin{array}{l}\text { Land occupation * } \\
\text { Water (as a medium for plant protection products)* } \\
\text { Emissions to air }\end{array}$} & ha & 1 & 1 & 1 \\
\hline & $\mathrm{L} \mathrm{ha}^{-1}$ & 2040 & 1470 & 557.5 \\
\hline & & & & \\
\hline \multirow{4}{*}{$\begin{array}{l}\text { Nitrogen oxides, } \mathrm{CZ} \\
\text { Dinitrogen monoxide } \\
\text { Ammonia, } \mathrm{CZ} \\
\text { Emissions to groundwater }\end{array}$} & $\mathrm{kg} \mathrm{ha}^{-1}$ & 1.75 & 1.21 & 0.31 \\
\hline & $\mathrm{kg} \mathrm{ha}^{-1}$ & 8.32 & 5.74 & 1.46 \\
\hline & $\mathrm{kg} \mathrm{ha}^{-1}$ & 11.86 & 6.01 & 10.29 \\
\hline & & & & \\
\hline \multirow{2}{*}{$\begin{array}{l}\text { Nitrate } \\
\text { Phosphorus }\end{array}$} & $\mathrm{kg} \mathrm{ha}^{-1}$ & 0.276 & 0.265 & 0.169 \\
\hline & $\mathrm{kg} \mathrm{ha}^{-1}$ & 0.848 & 0.266 & 0.275 \\
\hline
\end{tabular}

\# Basis is the treatment with the highest food oil yield (1 ha of winter rapeseed). * Input/s from the Ecoinvent, Agri-footprint, or WFLDB database. Transport was included in the process with a flat rate $10 \mathrm{~km} \times$ yield achieved ( $\max 8$ tons per load). $\mathrm{tkm}=$ tonne-kilometre; $\%{ }^{\mathrm{EL}}=$ share on the total environmental impact level; DM $=\mathrm{dry}$ matter.

\subsection{Determination of Field Emissions}

The usage of mineral nitrogenous fertilizers results in the release of so-called direct and indirect emissions of $\mathrm{N}_{2} \mathrm{O}, \mathrm{NH}_{3}, \mathrm{NO}_{3}{ }^{-}$, and $\mathrm{NO}_{\mathrm{x}}$ (expressed as dinitrogen monoxide and ammonia in Table 1). The following were taken into account in the monitoring of field and agricultural emissions: $\mathrm{NH}_{3}$ and $\mathrm{NO}_{x}$ volatilization, $\mathrm{NO}_{3}{ }^{-}$leaching to groundwater, and nitrogen loss from leaching and surface outflow [26]. The risk of erosion was not considered in this study. The production of pesticides and herbicides, their active substances, and their distribution has been taken into account using data from the Ecoinvent 3.7 database [23], 
but the fate of the pesticides in the environment was not taken into account. Therefore, the toxicity impact cannot be considered as fully reflected.

\subsection{Impact Assessment}

A life cycle assessment method was used for environmental load quantification. The system boundaries were set from the cradle to the farm gate. The results of this research are related to the selected midpoint impact categories of climate change $\left(\mathrm{kg} \mathrm{CO}_{2} \mathrm{eq}\right)$, terrestrial acidification ( $\mathrm{kg} \mathrm{SO}_{2} \mathrm{eq}$ ), freshwater eutrophication ( $\mathrm{kg} \mathrm{P} \mathrm{eq),} \mathrm{marine} \mathrm{eutrophication} \mathrm{(} \mathrm{g}$ $\mathrm{N}$ eq), terrestrial ecotoxicity (g 1,4-DB eq), freshwater ecotoxicity (g 1,4-DB eq), water depletion $\left(\mathrm{m}^{3} \mathrm{eq}\right)$, human toxicity ( $\mathrm{kg} \mathrm{1,4-DB} \mathrm{eq),} \mathrm{and} \mathrm{fossil} \mathrm{depletion} \mathrm{(} \mathrm{kg}$ oil eq). The Attributional approach was used for this study. Selected impact categories are suitable for agricultural LCAs [11,13]. SimaPro 9.2.0.1 software, ReCiPe Midpoint, Hierarchical (H) perspective V1.13/Europe Recipe H., an integrated method [27], and a cut-off system model approach were used for the assessment of the environmental aspects. One cubic metre of food oil and an area unit (land demand for generating the same volume of food oil) were used as functional units. The characterization approach was primarily used for data expression.

\subsection{Study Limitations and the Study Completeness Check}

Life cycle modelling of agricultural crops and subsequent evaluation of environmental impacts by the LCA method is a complex task. As the authors of the study, we are aware that there are always a number of issues that make objective and accurate evaluation difficult. (1) The study did not include the fate of pesticides and their metabolites in the environment, so the categories of ecotoxicity should not be considered complete. (2) The effect of the pre-crop, the balance of nutrients from the point of view of inputs from atmospheric deposition, mineralization, or decomposition, was not taken into account. (3) The case study was based on a dataset of standard cultivation procedures corresponding to the conditions of the Czech Republic. The results of the study, therefore, should not be considered as flat-rate. (4) The study compares the environmental impact associated with the volume of food oil production from rape, sunflower, and hemp, and the qualitative aspects of these oils were not taken into account.

\section{Results and Data Interpretation}

Based on the inventoried data and modelled standardized cultivation practices corresponding to the conditions of the Czech Republic, the results of environmental impact levels for winter rapeseed, sunflower, and hemp were determined, which correspond to nine impact categories. Characterization (Sections 3.1 and 3.2) and normalization (Section 3.3) approaches were used for data interpretation purposes.

\subsection{Interpretation Based on the Unit of Production}

Contribution analysis was performed for oil crop monocultures according to the characterization model (Figure 1). The results are related to nine impact categories and transferred to the environmental impact level in percentages. According to the data interpretation, it was also possible to define different environmental impacts between individual oil crops. The functional unit for this expression was one cubic metre of food oil. 


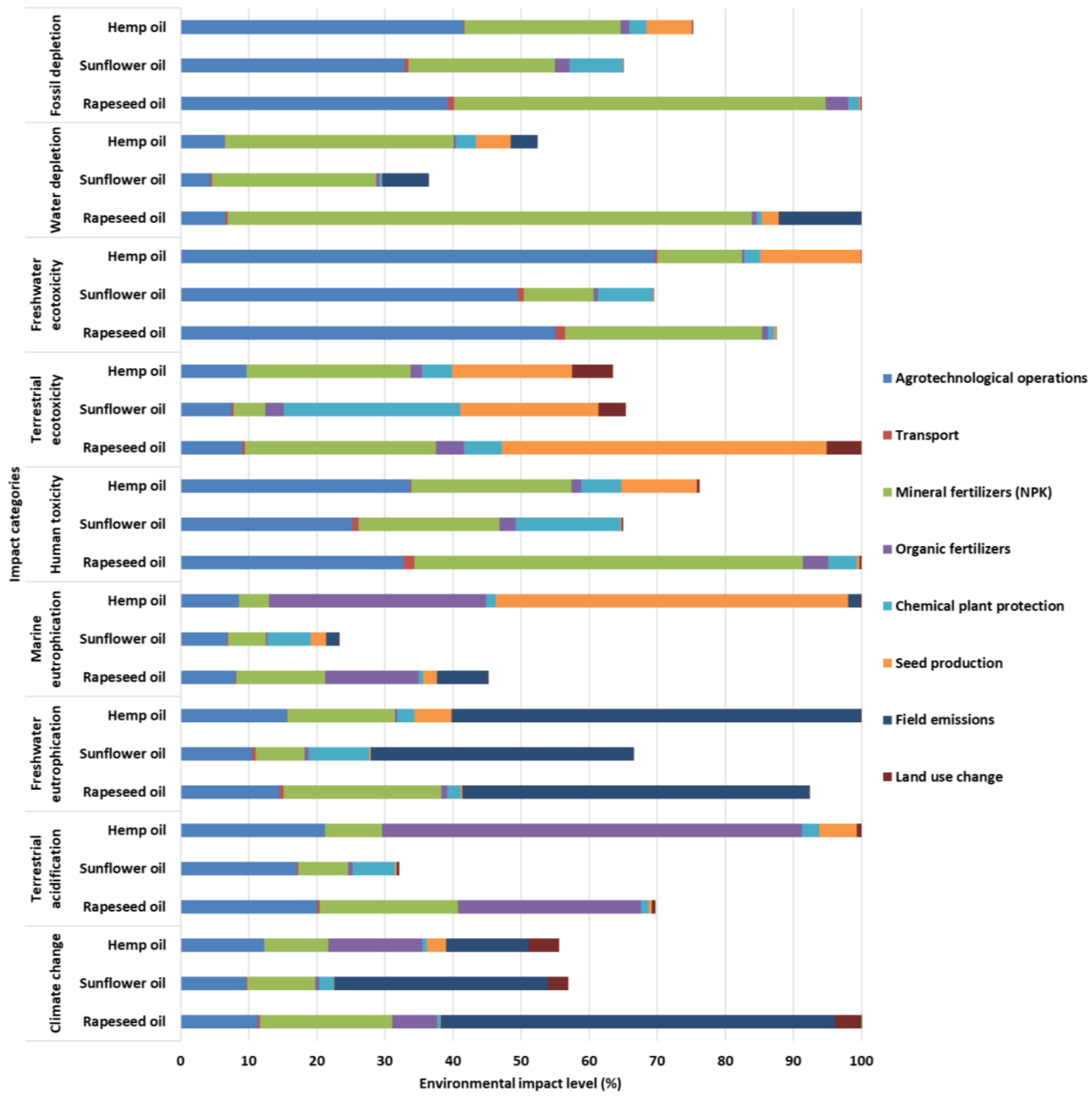

Figure 1. Environmental impact level for the unit of production ( $F U=1 \mathrm{~m}^{3}$ of food oil). Contribution analysis from the cradle-to-farm gate approach for environmental impacts; ReCiPe midpoint $(\mathrm{H})$ method, characterization model, results were expressed per $1 \mathrm{~m}^{3}$ of food oil.

According to the trend of interpreted data corresponding to the characterization model (Figure 1), the most significant environmental impact related to $1 \mathrm{~m}^{3}$ of food oil was connected with rapeseed food oil production in the impact category of climate change, human toxicity, terrestrial ecotoxicity, water depletion, and fossil depletion. Within the impact categories of terrestrial acidification, freshwater eutrophication, marine eutrophication, and freshwater ecotoxicity, the highest environmental impact related to $1 \mathrm{~m}^{3}$ of food oil was connected with hemp oil. The differences in environmental impact levels between individual oil crops and impact categories were important. According to models of life cycles, sunflower oil can be considered a product with the lowest environmental impact compared to hemp and rapeseed oil. According to results based on the FU of production, the environmental impact of $1 \mathrm{~m}^{3}$ of food oil production of sunflower seems to be more environmentally friendly in comparison to hemp oil or rapeseed oil. 
From the point of view of a contribution analysis, the impact on the environment was mainly reflected in the input of agrotechnologies and fertilizer production and utilization, and related to field emissions production. It was predominantly reflected in all the assessed impact categories. The inputs of agrotechnology-agrotechnical operations performed during pre-sowing tillage, fertilization and incorporation of fertilizers into the soil, application of plant protection products, and harvesting-had a substantial effect on the total environmental impact. These inputs were reflected mainly in the impact category of human toxicity, freshwater ecotoxicity, and fossil depletion, i.e., the category mostly related to the consumption of fossil fuels. A large share of the total impact on the environment belongs to the inputs of mineral fertilizers or their production and use. This input most affects the category of fossil depletion, water depletion, or human toxicity. In all cases, it was modelled with inputs of organic fertilizers (slurry or manure) and with the related field emissions. Their input does not manifest itself significantly. Apart from marine eutrophication, climate change, and terrestrial acidification (representing more than a $60 \%$ share of the environmental impact of hemp oil production), this input was low due to the nature and volume. Field emissions impact level then depended on the inputs of fertilizers (mineral and organic). In this study, the environmental impact associated with emissions to air (nitrogen oxides, dinitrogen monoxide, and ammonia) and emissions to groundwater (nitrate and phosphorus) from fertilizers were modelled. These emissions form a significant part of the environmental impact in the impact category of climate change (up to $55 \%$ in the case of winter rapeseed oil) and freshwater eutrophication (up to $60 \%$ in the case of hemp oil). Another input of growing cycles, with a relatively small impact (up to $6 \%$ on a total environmental load of impact categories), was land use. Land use was mainly reflected in the impact category of climate change and terrestrial ecotoxicity. The relatively high environmental impact was associated with the production and use of seeds (up to $50 \%$ in the case of hemp oil production, in terms of terrestrial ecotoxicity or marine eutrophication). The most affected impact category due to seed input and seed production was terrestrial ecotoxicity, and in comparison with the monitored oil crops, seed input was most pronounced for hemp. This affects the nature of the entry itself and the amount of seed needed to establish the stand (winter rapeseed 4, sunflower 5, and hemp $60 \mathrm{~kg} \mathrm{ha}^{-1}$ of seed). Due to the higher demand for hemp seeds for sowing, this input was also reflected in the impact category of marine eutrophication or freshwater ecotoxicity. The last input considered was the production and usage of chemical plant protection products (pesticides, herbicides, and growth regulators). In sum, these inputs did not exceed (within the individual impact categories) $10 \%$ of the total environmental impact, except in the case of sunflower oil production under the impact category of terrestrial ecotoxicity (about 25\% of the total environmental impact) and human toxicity (about 15\% of the total environmental impact). However, it should be noted that their following distribution in the environment and the potential impacts of their residues were not taken into account.

Results were highly dependent on the inputs of the cultivation strategy (inputs and outputs) and on the final yield of seeds and the gain of food oil. Another critical aspect was the allocation approach (mass allocation principle), which determines the final share of the environmental impact.

\subsection{Interpretation Based on Unit of Land Demand}

The results of the environmental impact assessment from the point of view of the functional unit of area (the area of land needed for the generation of the same volume of food oil) differ widely from the assessment associated with the functional unit of production. The functional unit of equivalent area (land demand for generating the same volume of food oil) brought a significant change in the trend of environmental impacts. In the case of hemp, 6.8 ha were needed for the same volume of food oil which can be produced with 1.0 ha of land for winter rapeseed and 1.3 ha for sunflowers. From this perspective, hemp oil production was connected with the highest environmental impact in comparison to sunflower and rapeseed food oil production (Figure 2) within all assessed impact categories. 
The environmental impact level of hemp was affected by the high land demand and the related more substantial inputs to the life cycle and cultivation strategy.

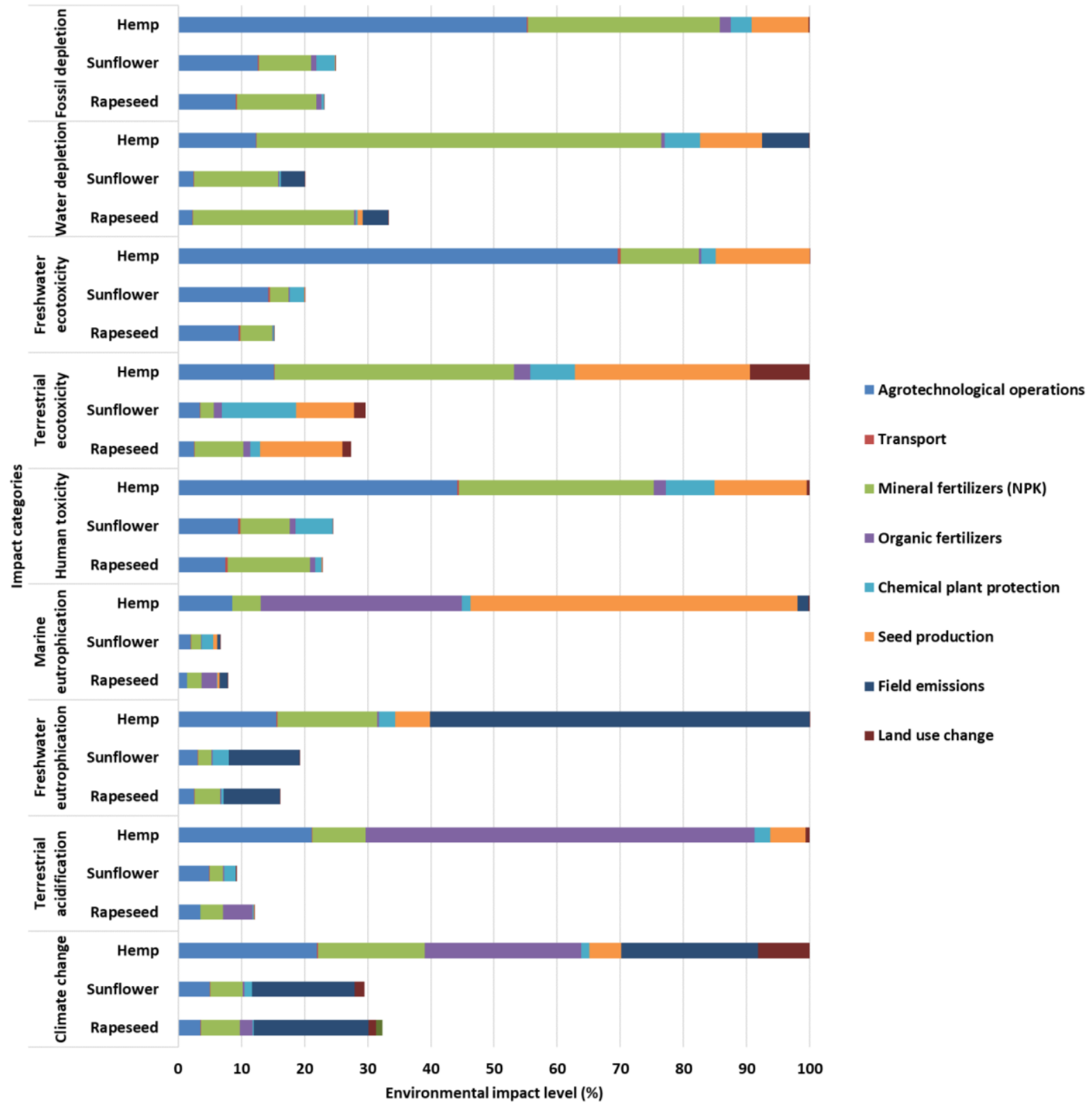

Figure 2. Environmental impact level for the unit of area (FU = land demand for generating the same volume of food oil). Contribution analysis from the cradle-to-farm gate approach for environmental impacts; ReCiPe midpoint $(\mathrm{H})$ method, characterization model, results were expressed per land demand for generating the same volume of food oil.

Compared to the evaluation related to the functional unit of production, significant changes were found in hemp. The influence of field emissions and fertilizer inputs (mineral and organic) are most pronounced, though all inputs related to the growing cycle are represented. This was a proportional increase in the environmental impact, reflecting the higher demand for land to produce the same amount of food oil as rape and sunflower. The total environmental impact would increase two to nine times compared to sunflower or winter rapeseed, which showed a completely different trend. Thus, it turned out that assessing environmental impacts from the point of view of a unit of area is essential for a fair comparative study. 


\subsection{Normalization and the Data Weighing}

Normalization of data sets was applied to take into account the most affected impact categories. No contribution analysis was employed for normalizations because percentage terms for individual impact categories would give identical characteristics to the characterization model. However, normalization is important for detecting the most affected categories, and therefore the components of the environment. Data normalization was done for both specified functional units (Figures 3 and 4).

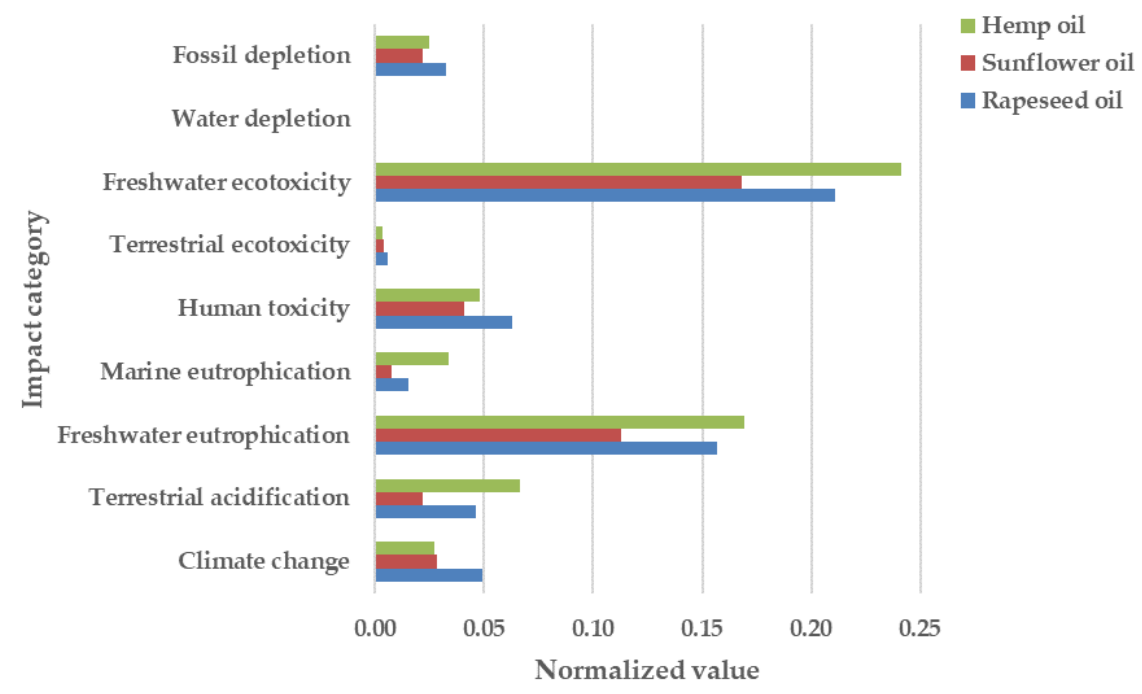

Figure 3. Normalization model for the unit of production (FU $=1 \mathrm{~m}^{3}$ of food oil). From the cradle-tofarm gate approach for environmental impacts; ReCiPe midpoint $(\mathrm{H})$ method, normalization model, results were expressed per $1 \mathrm{~m}^{3}$ of food oil.

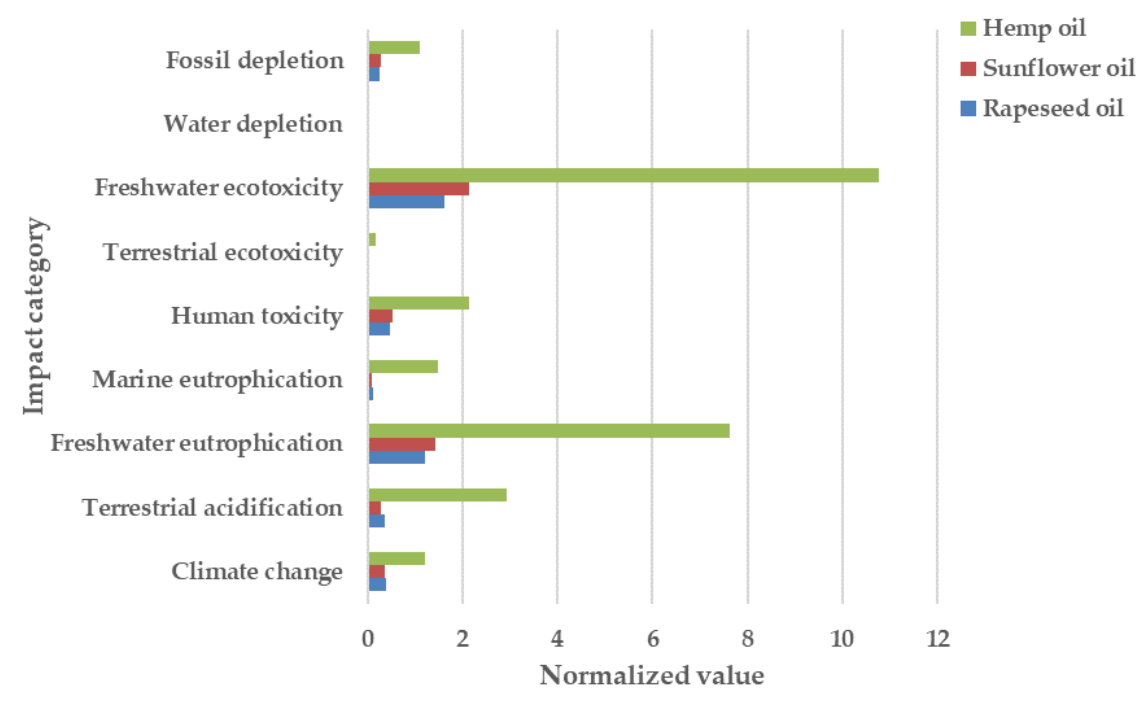

Figure 4. Normalization model for the unit of area (FU = land demand for generating the same volume of food oil). From the cradle-to-farm gate approach for environmental impacts; ReCiPe midpoint $(\mathrm{H})$ method, normalization model, results were expressed per land demand for generating the same volume of food oil.

Following the normalization model (Figure 3), most affected were the categories of eutrophication and ecotoxicity. Fertilizer treatment, related field emissions, and agrotechnology creation were the most significant sources of environmental impact. In the impact category of fossil depletion, terrestrial ecotoxicity, human toxicity, and climate change, rapeseed oil production was related to the highest environmental impact. In the impact category of freshwater ecotoxicity, marine eutrophication, freshwater eutrophication, and 
terrestrial acidification, hemp oil was characterized by the highest environmental impact. The trend of environmental impact level points to the lower impact related to sunflower oil production ( $\mathrm{FU}=1 \mathrm{~m}^{3}$ of food oil).

A comparison of selected oil crops based on the normalization model was also made within the land demand for generating the same volume of food oil (Figure 4). According to the results, the impact categories with the highest environmental impact were the categories of eutrophication and ecotoxicity, which was similar to FU production $\left(\mathrm{m}^{3}\right.$ of food oil). However, due to the higher demand for land in the case of hemp, the highest environmental impact was associated with the production of hemp oil in all assessed impact categories. The most striking increase was found in the category of freshwater ecotoxicity, freshwater eutrophication, terrestrial acidification, and human toxicity.

Although weighing provides only a general view of the overall environmental impact assessment, it is a suitable tool for data trend interpretation. A combination of both specified functional units within the weighing is suitable for data interpretation. Such a data expression can provide a comprehensive view of the assessed issues and thus determine the cultivation strategy, in this case, the oil crop with the lowest overall impact on the environment, and vice versa. This overall comparison is part of Figure 5.

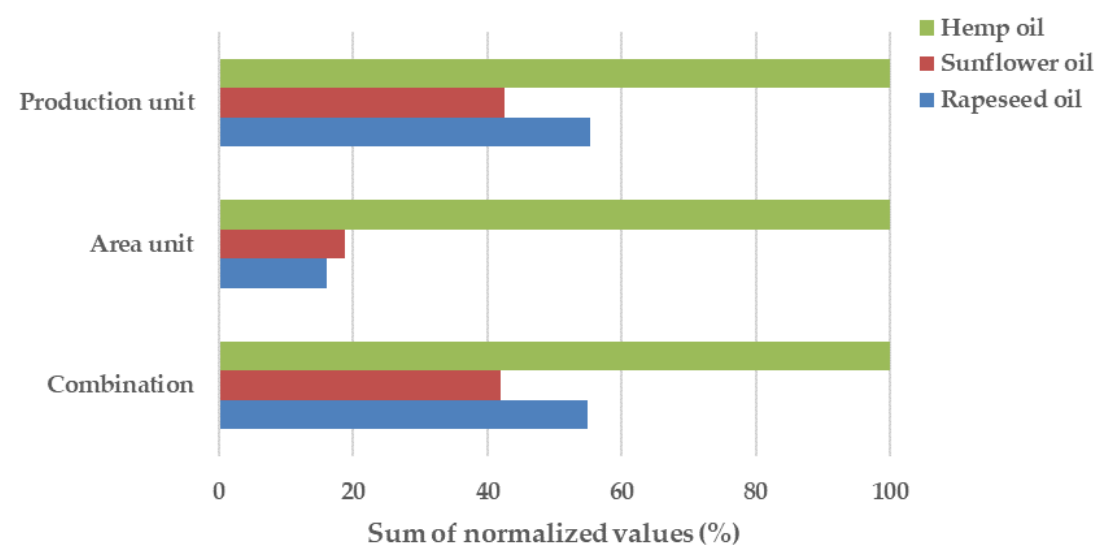

Figure 5. Weighing based on normalization mode. Production unit $=1 \mathrm{~m}^{3}$ of food oil; Area unit = land demand for generating the same volume of food oil; Combination = interpretation based on the merger of both functional units.

According to the established study framework and models presenting winter rapeseed, sunflower, and hemp cultivation technologies, the environmental impacts were quantified according to the functional unit of production $\left(1 \mathrm{~m}^{3}\right.$ of food oil $)$ and the unit of land (land demand for generating the same volume of food oil) within nine impact categories corresponding to agricultural LCA. Thus, two perspectives with different trends of environmental impacts were obtained. Within the evaluation of FU production $\left(\mathrm{m}^{3}\right.$ of food oil), the highest impacts on the environment were associated with the production of hemp oil (Figure 5). Within the evaluation of the FU area (land demand for generating the same volume of food oil), the highest impacts on the environment were also associated with the production of hemp oil. The principle of data weighing, combining both functional units (Figure 5), was used to summarise the obtained data. Thus, a general trend for individual oil crops was obtained. From this point of view, sunflower oil production appeared to be the variant with the lowest overall impact on the environment, which was about $60 \%$ lower compared to the production of hemp oil, and about $20 \%$ lower compared to the production of rapeseed oil.

Within agricultural LCAs, the scope for detailed and deep discussion is often limited to methodological issues, as studies differ in their frameworks, data quality, and character, as well as their interpretations. Presenting the results as trends is thus a logical step, one that gives the discussion greater generality and makes it more readily understandable for readers. 


\section{Discussion and Perspective}

A life cycle assessment method was chosen to model the life cycle of winter oil crops (rapeseed, sunflower, and hemp as an alternative). Due to its complexity, LCA is a very popular environmental management tool [13]. The results were related to impact categories corresponding to the requirements for the agricultural LCAs [11]. The approach to the elaboration of this study, the approach to modelling, the allocation approach, the functional unit (volume of food oil), the software used, and the source databases were similar to, for example, the study of Fridrihsone et al. [28,29], which also focused on oil crops.

Agriculture is widely perceived as a multifunctional production process. In addition to food, animal feed, and energy sources, non-commodity outputs, such as landscape management and ecosystem services, are also generated. However, LCA studies often focus only on the ecological/environmental sustainability of agricultural products, expressed in terms of impacts per unit of production, without any allocation between commodity and non-commodity outputs. This narrow view, which focuses only on production efficiency, can often favour conventional agricultural products, although when evaluated by other methods, these systems prove to be less environmentally friendly and less sustainable [30-32]. The solution to the issue of multifunctionality lies in choosing another functional unit that allows multifunctional outputs or allocating environmental impacts to the whole complex of products and services provided within the agricultural system [33]. The choice of the functional unit determines the nature of the study outputs and their interpretation and is one of the key moments in implementing the LCA study [34]. If the product has more functions, it is always necessary to select those relevant for the assessed system [35]. The functional unit provides the basis on which the input and output data are related. It must be clearly definable and measurable [21]. The functional unit thus expresses the measurable size of the function that we expect from the product system [35]. The universal solution seems to be to use both methods of calculating the environmental impact, both per unit area and per production unit $[19,36]$. Recent criticism points to the fact that these two functional units do not affect product quality, which can play a key role in defining product function. An example can be the types of quality wine [10]. In the LCA study of an agricultural commodity, more functional units should ideally be chosen for the examined system, contributing to a complete evaluation from several perspectives [37]. In addition, this step would clearly improve the comparability of the results with other studies of the same product [10].

The environmental aspects of rapeseed cultivation, from the LCA perspective, have recently received a relatively large amount of attention (e.g., [8,9,28,29]). This is because rapeseed oil was long thought to cause a lower environmental impact compared to mineral oils, for example. However, it has been shown that the systems running on rapeseed oil are not necessarily better for the environment. Many of the environmental issues examined in one study were affected more negatively by the use of rapeseed oil than mineral oil. The main exception to this was greenhouse gas emissions, which are consistently higher for systems using mineral oil because of the use of fossil resources for rapeseed oil production [38]. As Stow et al. [39] stated, biodiesel based on rapeseed is often considered to improve energy security and reduce the impact of fuel on climate change. However, there are concerns about the impact of biodiesel when its life cycle is considered. The potential impact of using biodiesel rather than conventional diesel was investigated using a life cycle assessment (LCA) of rapeseed biodiesel. Biodiesel leads to reduced fossil fuel use and is likely to reduce the impact of transport on climate change. However, it was found that the impact of biodiesel towards other categories, i.e., land use and respiratory inorganics (Particulate matter; PM2.5), was greater than petroleum diesel. Therefore, biodiesel production should be carefully managed to mitigate its impact on the environment.

Our study shows how the cultivation practices and the type/quantity of input influence the total environmental impact. Using the Life Cycle Assessment (LCA) method to assess the environmental impact of rapeseed and sunflower was also performed in the study of Palmieri et al. [8]. The study presents similar findings to ours. The practice 
of intensive farming with high fertilization and mechanization (machinery and fertilizer production and application) is responsible for the high environmental impact. However, when the level of productivity is low, the impact is still higher [8]. The results of our study also show that the highest environmental impacts would be associated with the production of hemp oil in comparison with rapeseed oil and sunflower oil. The results of Iriate et al. [40] also indicated that, compared to sunflower, rapeseed production has a better environmental performance (in nine out of the eleven impact categories evaluated) and lower water consumption. Although this study did not use the same methodological approach and framework to the present study, the trend of environmental aspects is similar. Iriate et al. [40] added that the energy demand of rapeseed is $4.9 \mathrm{GJ} \mathrm{t}^{-1}$ seed, $30 \%$ less than that of sunflower. Mineral fertilizers cause the highest environmental impact. According to Queiros et al. [41], the choice of fertilizer has strong implications for environmental impacts. The production of nitrogen fertilizers makes significant contributions to abiotic depletion, global warming, ozone layer depletion, and photochemical oxidation. The analysis of the life cycle of fertilizers indicates that extraction of raw materials and their production are key stages. Attempts to reduce the environmental impact and energy requirement of both crops should be mainly associated with the evaluation of other types of fertilization. In addition, particularly for sunflowers, low-impact herbicides should be evaluated, seed yield improved, and cultivation practices optimized [40].

Based on the study results and the assessed framework, a number of inputs contribute to the total environmental impact, and one of the most important is agrotechnical operations in general. The impact of agricultural technology was significantly reflected in the category of freshwater ecotoxicity (about $50-70 \%$ of the total impact when the FU of production was considered), where the main role was played by fuel and energy consumption. Other significantly affected categories are fossil depletion (about 33-42\%) and human toxicity (about 25-33\%). From a general point of view, agrotechnical operations can be divided into those that need fuel for their operation (chief amongst which is diesel-based agriculture) and those that need electricity or natural gas. The need for natural gas (e.g., for heating greenhouses) did not occur in the evaluated study. Post-harvest processing of agricultural raw materials (in our case, food oil processing was not reflected in the study framework) and irrigation systems both depend on electricity (though not in the case of this study). With respect to common field operations and fuel consumption, ploughing was a major factor (and thus a place to improve the product's environmental profile). Based on the study result, ploughing also had one of the dominant roles among agrotechnical inputs. One possibility for optimization is to shift to reduced or even no-tillage systems. Fuel consumption and energy input are much lower than in the conventional tillage system using a plough, but yields do not differ, as shown for maize, soybean, sugar beet, and winter wheat [42-44]. Minimization technologies or no-till systems are an alternative to energy-intensive operations. They use shallower tillage [45,46], e.g., by loosening or sowing surface-treated or untreated soil [47]. However, the impact on the final yield level has to be considered [46].

One of the most important inputs in the agricultural phase is that of fertilizers (organic and inorganic) [48,49]. For the reduction of greenhouse gas emissions from agricultural crop production, it is proposed to reduce the doses of nitrogen fertilizers used [50]. Reducing doses, especially of synthetic nitrogen, brings significant economic savings, in addition to the environmental benefits, which could provide an incentive for farmers to manage nitrogen properly, including the use of closed-cycle N-cycle recycling techniques [51]. It is also necessary to follow the principles of proper management of nitrogen fertilizers [52]. Furthemore, the nitrogen that is accessible through biological fixation is potentially high, as shown for faba beans and peas [53], not just in organic systems but also in conventional farming where nitrogen fertilizer is used $[54,55]$. The reduction of synthetic fertilizers can also be achieved through organic farming [56] or agroecological techniques [57]. Both of these concepts have a long tradition in the Czech Republic [58]. However, organic production is often associated with lower production per unit area, and with it often higher 
environmental pressures [59]. One way to support the reduction of the environmental impact of organic farming is to increase its yields while maintaining existing inputs [60]. This can be achieved, for example, by using a more balanced sowing procedure or by more efficient application and use of fertilizers [48]. The significant contribution of nitrogen fertilizers to the environmental impacts of rapeseed cultivation emphasizes the need for efficient nutrient management practices in order to minimize the application rates required [41]. Precise agricultural practices can be used for the purposes of minimizing fertilizer doses. For example, Nedbal et al. [61] showed how the most modern methods of spectral evaluation of plant nutrition can be used to calculate precise doses of nitrogen fertilizer. These techniques can help to decrease the leaching of nitrates into ground and surface water.

Transport is usually an important part of the life cycle assessment of agriculture and food production. Its importance and impact are growing mainly due to globalization tendencies [62]. It is often expressed in terms of "food miles", which summarize all the logistical routes of a product between farmers, producers, and consumers [63]. In the evaluated cycles, the transport was created using a tonne-kilometre (tkm), which expresses the transport of one ton of cargo over a distance of one kilometre. All modelled transport was realized with the help of road freight transport, and the transport distance was considered in the study to be $10 \mathrm{~km}$. Only transport between the field and the farm was taken into account in the study. Overall, transport can be considered a minority input, as its share within the individual impact categories did not exceed $5 \%$.

Based on the study results, the input of plant protection products did not exceed a $10 \%$ share of the total impact. However, it should be noted that the fate of pesticides in the environment was not considered, but only their impact arising from the production and application as represented in the databases (Ecoinvent v3.7 [23], Agri-footprint v4.0 [24], and WFLDB [25]). Within agricultural LCAs, field emissions of pesticides are quantified by modelling [64]. Despite the fact that from the point of view of the established framework and the nature of the inputs, sunflower and rape appear to be more environmentally friendly options compared to hemp, it is necessary to take into account aspects related to the use of pesticides. The fate of pesticides in the environment and their impact can be crucial when deciding on the application of plant cultivation strategies or their removal from the environment [65]. Based on the study related to the Czech Republic, the side effects of pesticides are one of the major factors often linked to bee colony losses. The most important pesticides related to the poisoning incidents were highly toxic chlorpyrifos, deltamethrin, cypermethrin, imidacloprid, and slightly toxic prochloraz and thiacloprid. Importantly, poisoning was associated with pesticide cocktail applications. Almost all poisoning incidents were investigated in relation to rapeseed [66]. Sunflower cultivation is also highly dependent on pesticides [67]. It is common practice in the Czech Republic to apply fungicides and pesticides together. This step also has an impact on biodiversity, including bee populations [68]. In contrast, hemp is grown without agrochemical inputs without any problems [17], thus eliminating the negative factors associated with them. It is still important to monitor the fate of pollutants and foreign substances in the environment. Due to the importance of the topic, this is an issue requiring appropriate attention. There are still many questions about the transport and behaviour of pollutants, their interactions with other substances, and the impact on human health. Effective ways for reducing their usage and achieving suitable management must be found [69].

Compared to sunflowers and rapeseed, hemp production has several other significant environmental benefits [70]. One of these is high sequestration. The soil carbon change associated with different agricultural management practices is an important factor contributing to the global warming impact [41]. In the case of hemp production, sequestration is up to $2500 \mathrm{~kg} \mathrm{CO}_{2}$ per ha per year [71]. In the case of rapeseed, carbon sequestration to soils varies between $112 \mathrm{~kg} \mathrm{CO}$ eq/1000 kg dry seeds (cool temperate dry climate) and $271 \mathrm{~kg} \mathrm{CO}$ eq/1000 kg dry seeds (warm temperate moist climate) [41]. According to Halvorson et al. [72], with no-till, an estimated $854 \mathrm{~kg} \mathrm{CO}_{2} \mathrm{ha}^{-1}$ was sequestered each year 
in the annual crop system, which included sunflowers, compared with $92 \mathrm{~kg} \mathrm{CO}_{2} \mathrm{ha}^{-1}$ with minimum till and a loss of $517 \mathrm{~kg} \mathrm{CO}_{2} \mathrm{ha}^{-1}$ with conventional till. With respect to carbon sequestration, soils with high organic carbon content should not be converted to rapeseed cultivation to avoid excessive carbon emissions [41]. Another benefit of hemp that was not taken into account in the study is soil erosion. Whereas sunflowers belong to the category of plants with high erosion risk, and rapeseed belongs to the category of plants with mean erosion risk [73], hemp can enrich and stabilize unproductive lands by reducing weed pressure and soil erosion [70].

The demand for hemp products is growing. Hemp is considered an environmentally friendly crop with a lower environmental impact and higher yields, and can replace traditional materials used in the building, car, textile, paper, and biofuel industries. In addition to these benefits, hemp is also used in the food industry, as hemp seeds are rich in fat and proteins. Furthermore, demand for dietary supplements will grow as more consumers are looking for healthy or vegan food alternatives [5]. Hemp is an excellent plant for cultivation in organic farming systems [74] and is suitable for crop rotation [75].

\section{Conclusions}

The study presents the results of environmental impact assessments from the perspective of an agricultural LCA. The results concern the environmental issues associated with the production of vegetable food oil. According to the established study framework and data corresponding to standard cultivation practices for winter rape, sunflower, and hemp, hemp cultivation for food oil production may not meet the high sustainability predictions and low environmental impacts that are currently claimed for it. In this respect, the inputs to the growing cycle, and especially the low yields of food oil compared to traditional and efficient oils crops, including winter rape and sunflower, are significant. The applied methodological approach and interpretation of data in this study showed that the total environmental impact (based on the combination of production and area unit) associated with the production of hemp oil (volume of food oil) was about $40 \%$ higher than rapeseed oil and about $60 \%$ higher than sunflower oil.

Author Contributions: Conceptualization, J.B., T.B., V.N., and R.W.N.; methodology, J.B.; software, J.B.; validation, J.B., T.B., V.N., and R.W.N.; formal analysis, J.B., T.B., V.N., and R.W.N.; investigation, J.B.; resources, J.B.; data curation, J.B., T.B., V.N., and R.W.N.; writing-original draft preparation, J.B., T.B., V.N., and R.W.N.; visualization, J.B., T.B., V.N., and R.W.N.; supervision, R.W.N.; funding acquisition, T.B. All authors have read and agreed to the published version of the manuscript.

Funding: The research was financially supported by the Grant Agency of the University of South Bohemia in České Budějovice, Czech Republic under grant number GA JU 045/2019/Z, and by the Faculty of Agriculture, the University of South Bohemia in České Budějovice.

Institutional Review Board Statement: Not applicable.

Informed Consent Statement: Not applicable.

Data Availability Statement: All the data related to this manuscript are available in this document or they were cited in the references.

Acknowledgments: The authors would like to thank the Faculty of Agriculture, the University of South Bohemia in České Budějovice, for their financial and material support. We would like to thank our colleagues for their help with administrative support and manuscript preparation. We finally want to warmly thank the anonymous reviewers for their comments, which improved the quality of the paper.

Conflicts of Interest: The authors declare no conflict of interest.

\section{References}

1. Carré, P.; Pouzet, A. Rapeseed Market, Worldwide and in Europe. OCL 2014, 21, D102. [CrossRef]

2. Dvořáková, M. Situační a Výhledová Zpráva Olejniny; Ministerstvo zemědělství: Praha, Czech Republic, 2019; ISBN 978-80-7434586-9. 
3. CZSO (The Czech Statistical Office). Prague: Integrated Operational Program; Uropean Union: Prague, Czech Republic. Available online: https:/ / www.czso.cz/csu/czso/home (accessed on 17 May 2021).

4. Cherney, J.; Small, E. Industrial Hemp in North America: Production, Politics and Potential. Agronomy 2016, 6, 58. [CrossRef]

5. Dhondt, F.; Muthu, S.S. Sustainable Hemp Products. In Hemp and Sustainability; Sustainable Textiles: Production, Processing, Manufacturing \& Chemistry; Springer: Singapore, 2021; pp. 95-107. ISBN 9789811633331.

6. Poore, J.; Nemecek, T. Reducing Food's Environmental Impacts through Producers and Consumers. Science 2018, 360, 987-992. [CrossRef] [PubMed]

7. Bunzel, K.; Kattwinkel, M.; Schauf, M.; Thrän, D. Energy Crops and Pesticide Contamination: Lessons Learnt from the Development of Energy Crop Cultivation in Germany. Biomass Bioenergy 2014, 70, 416-428. [CrossRef]

8. Palmieri, N.; Forleo, M.B.; Suardi, A.; Coaloa, D.; Pari, L. Rapeseed for Energy Production: Environmental Impacts and Cultivation Methods. Biomass Bioenergy 2014, 69, 1-11. [CrossRef]

9. Fridrihsone, A.; Romagnoli, F.; Cabulis, U. Life Cycle Inventory for Winter and Spring Rapeseed Production in Northern Europe. J. Clean. Prod. 2018, 177, 79-88. [CrossRef]

10. Notarnicola, B.; Salomone, R.; Petti, L.; Renzulli, P.A.; Roma, R.; Cerutti, A.K. (Eds.) Life Cycle Assessment in the Agri-Food Sector; Springer International Publishing: Cham, Germany, 2015; ISBN 978-3-319-11939-7.

11. Dijkman, T.J.; Basset-Mens, C.; Antón, A.; Núñez, M. LCA of Food and Agriculture. In Life Cycle Assessment; Hauschild, M.Z., Rosenbaum, R.K., Olsen, S.I., Eds.; Springer International Publishing: Cham, Germany, 2018; pp. 723-754. ISBN 978-3-319-56474-6.

12. Meier, M.S.; Stoessel, F.; Jungbluth, N.; Juraske, R.; Schader, C.; Stolze, M. Environmental Impacts of Organic and Conventional Agricultural Products-Are the Differences Captured by Life Cycle Assessment? J. Environ. Manag. 2015, 149, 193-208. [CrossRef] [PubMed]

13. Hauschild, M.Z.; Olsen, S.I.; Rosenbaum, R.K. (Eds.) Life Cycle Assessment: Theory and Practice, 1st ed.; Springer: Cham, Germany, 2018; ISBN 978-3-319-56475-3.

14. Common Agricultural Policy (CAP). Sustainable agriculture in the Common Agricultural Policy. European Commission. 2021. Available online: https:/ / ec.europa.eu/info/food-farming-fisheries/sustainability/sustainable-cap_en/ (accessed on 24 January 2021).

15. Mattsson, B.; Cederberg, C.; Blix, L. Agricultural Land Use in Life Cycle Assessment (LCA): Case Studies of Three Vegetable Oil Crops. J. Clean. Prod. 2000, 8, 283-292. [CrossRef]

16. Eurostat. Agriculture-Overview. 2021. Available online: https://ec.europa.eu/eurostat/web/agriculture. (accessed on 18 October 2021).

17. Carus, M.; Sarmento, L. The European Hemp Industry: Cultivation, Processing and Applications for Fibres, Shivs, Seeds and Flowers; European Industrial Hemp, Belgium Association: Brusel, Belgium, 2016; pp. 1-9.

18. Bernas, J.; Konvalina, P.; Burghila, D.V.; Teodorescu, R.I.; Bucur, D. The Energy and Environmental Potential of Waste from the Processing of Hulled Wheat Species. Agriculture 2020, 10, 592. [CrossRef]

19. Bernas, J.; Bernasová, T.; Gerstberger, P.; Moudrý, J.; Konvalina, P.; Moudrý, J. Cup Plant, an Alternative to Conventional Silage from a LCA Perspective. Int. J. Life Cycle Assess 2021, 26, 311-326. [CrossRef]

20. ISO. 14040-Environmental Management-Life Cycle Assessment-Principles and Framework; International Organization for Standardization: Geneva, Switzerland, 2006.

21. ISO. 14044-Environmental Management-Life Cycle Assessment-Requirements and Guidelines; International Organization for Standardization: Geneva, Switzerland, 2006.

22. Agronormativy. Normativy pro Zemědělskou a Potravinářskou výrobu: AGroConsult. 2015. Available online: http://www. agronormativy.cz/ (accessed on 5 April 2021).

23. Wernet, G.; Bauer, C.; Steubing, B.; Reinhard, J.; Moreno-Ruiz, E.; Weidema, B. The Ecoinvent Database Version 3 (Part I): Overview and Methodology. Int. J. Life Cycle Assess 2016, 21, 1218-1230. [CrossRef]

24. Durlinger, B.; Koukouna, E.; Broekema, R.; Van Paassen, M.; Scholten, J. Agri-Footprint 4.0-Part 1: Methodology and Basic Principles; Agri-Footprint: Gouda, The Netherlands, 2017; p. 52.

25. Nemecek, T.; Bengoa, X.; Lansche, J.; Roesch, A.; Faist-Emmenegger, M.; Rossi, V.; Humbert, S. Methodological Guidelines for the Life Cycle Inventory of Agricultural Products. Version 3.5. December 2019. World Food LCA Database (WFLDB); Quantis and Agroscope: Lausanne, Switzerland; Zurich, Switzerland, 2019; p. 88.

26. Nemecek, T.; Kägi, T. Life Cycle Inventories of Swiss and European Agricultural Production Systems. Final Report Ecoinvent V2.0 No. 15a, 1st ed.; AgroscopeReckenholz-Taenikon Research Station ART; Swiss Centre for Life Cycle Inventories: Zürich, Switzerland; Dübendorf, Switzerland, 2007; p. 360.

27. Pre Consultants, ReCiPe 2021 [WWW Document]. Available online: https://pre-sustainability.com/articles/recipe/ (accessed on 14 September 2021).

28. Fridrihsone, A.; Romagnoli, F.; Cabulis, U. Environmental Life Cycle Assessment of Rapeseed and Rapeseed Oil Produced in Northern Europe: A Latvian Case Study. Sustainability 2020, 12, 5699. [CrossRef]

29. Fridrihsone, A.; Romagnoli, F.; Kirsanovs, V.; Cabulis, U. Life Cycle Assessment of Vegetable Oil Based Polyols for Polyurethane Production. J. Clean. Prod. 2020, 266, 121403. [CrossRef]

30. Gibbs, K.E.; Mackey, R.L.; Currie, D.J. Human Land Use, Agriculture, Pesticides and Losses of Imperiled Species. Divers. Distrib. 2009, 15, 242-253. [CrossRef] 
31. Geiger, F.; Bengtsson, J.; Berendse, F.; Weisser, W.W.; Emmerson, M.; Morales, M.B.; Ceryngier, P.; Liira, J.; Tscharntke, T.; Winqvist, C.; et al. Persistent Negative Effects of Pesticides on Biodiversity and Biological Control Potential on European Farmland. Basic Appl. Ecol. 2010, 11, 97-105. [CrossRef]

32. Meehan, T.D.; Werling, B.P.; Landis, D.A.; Gratton, C. Agricultural Landscape Simplification and Insecticide Use in the Midwestern United States. Proc. Natl. Acad. Sci. USA 2011, 108, 11500-11505. [CrossRef] [PubMed]

33. Schader, C.; Stolze, M.; Gattinger, A. Environmental performance of organic farming. In Green Technologies in Food Production and Processing; Food Engineering Series; Boye, J.I., Arcand, Y., Eds.; Springer: Boston, MA, USA, 2012; pp. 183-210, ISBN 978-1-46141586-2.

34. Kočí, V. Na LCA založené Srovnání Environmentálních Dopadi̊ Obnovitelných Zdrojů Energie: Odhad LCA Charakterizačních Profilů Výroby Elektrické Energie z Obnovitelných Zdrojů Energie v ČR pro Projekt OZE-RESTEP; LCA Studio, VŠCHT: Praha, Czech Republic, 2012.

35. Kočí, V. Posuzování životního cyklu Life Cycle Assessment-LCA; Vodní zdroje Ekomonitor: Chrudim, Czech Republic, 2009; ISBN 97880-86832-42-5.

36. Schau, E.M.; Fet, A.M. LCA Studies of Food Products as Background for Environmental Product Declarations. Int. J. Life Cycle Assess 2008, 13, 255-264. [CrossRef]

37. Seda, M.; Antòn, A.; Munoz, P. Analyzing the Influence of the Functional Unit in Agricultural LCA. In Proceedings of the 7th International Conference on Life Cycle Assessment in the Agri-food Sector, Bari, Italy, 22-24 September 2010; pp. 85-90.

38. McManus, M.C.; Hammond, G.P.; Burrows, C.R. Life-Cycle Assessment of Mineral and Rapeseed Oil in Mobile Hydraulic Systems. J. Ind. Ecol. 2003, 7, 163-177. [CrossRef]

39. Stow, M.; McManus, M.C.; Bannister, C. A life cycle assessment comparison of rapeseed biodiesel and conventional diesel. In Sustainable Vehicle Technologies: Driving the Green Agenda 14-15 November 2012, Gaydon, Grande-Bretagne, Proceedings of the Sustainable Vehicle Technologies Conference; Woodhead Publishing: Oxford, UK, 2012; ISBN 978-0-85709-456-8.

40. Iriarte, A.; Rieradevall, J.; Gabarrell, X. Life Cycle Assessment of Sunflower and Rapeseed as Energy Crops under Chilean Conditions. J. Clean. Prod. 2010, 18, 336-345. [CrossRef]

41. Queirós, J.; Malça, J.; Freire, F. Environmental Life-Cycle Assessment of Rapeseed Produced in Central Europe: Addressing Alternative Fertilization and Management Practices. J. Clean. Prod. 2015, 99, 266-274. [CrossRef]

42. Moitzi, G.; Neugschwandtner, R.W.; Kaul, H.-P.; Wagentristl, H. Energy Efficiency of Winter Wheat in a Long-Term Tillage Experiment under Pannonian Climate Conditions. Eur. J. Agron. 2019, 103, 24-31. [CrossRef]

43. Moitzi, G.; Neugschwandtner, R.W.; Kaul, H.-P.; Wagentristl, H. Comparison of Energy Inputs and Energy Efficiency for Maize in a Long-Term Tillage Experiment under Pannonian Climate Conditions. Plant Soil Environ. 2021, 67, 45-52. [CrossRef]

44. Moitzi, G.; Neugschwandtner, R.W.; Kaul, H.-P.; Wagentristl, H. Effect of Tillage Systems on Energy Input and Energy Efficiency for Sugar Beet and Soybean under Pannonian Climate Conditions. Plant Soil Environ. 2021, 67, 137-146. [CrossRef]

45. Soane, B.D.; Ball, B.C.; Arvidsson, J.; Basch, G.; Moreno, F.; Roger-Estrade, J. No-till in Northern, Western and South-Western Europe: A Review of Problems and Opportunities for Crop Production and the Environment. Soil Tillage Res. 2012, 118 , 66-87. [CrossRef]

46. Houshyar, E.; Grundmann, P. Environmental Impacts of Energy Use in Wheat Tillage Systems: A Comparative Life Cycle Assessment (LCA) Study in Iran. Energy 2017, 122, 11-24. [CrossRef]

47. Känkänen, H.; Alakukku, L.; Salo, Y.; Pitkänen, T. Growth and Yield of Spring Cereals during Transition to Zero Tillage on Clay Soils. Eur. J. Agron. 2011, 34, 35-45. [CrossRef]

48. Brentrup, F.; Küsters, J.; Lammel, J.; Barraclough, P.; Kuhlmann, H. Environmental Impact Assessment of Agricultural Production Systems Using the Life Cycle Assessment (LCA) Methodology II. The Application to N Fertilizer Use in Winter Wheat Production Systems. Eur. J. Agron. 2004, 20, 265-279. [CrossRef]

49. Hasler, K.; Bröring, S.; Omta, S.W.F.; Olfs, H.-W. Life Cycle Assessment (LCA) of Different Fertilizer Product Types. Eur. J. Agron. 2015, 69, 41-51. [CrossRef]

50. Smith, P.; Martino, D.; Cai, Z.; Gwary, D.; Janzen, H.; Kumar, P.; McCarl, B.; Ogle, S.; O’Mara, F.; Rice, C.; et al. Greenhouse Gas Mitigation in Agriculture. Phil. Trans. R. Soc. B 2008, 363, 789-813. [CrossRef]

51. Stolze, M.; Piorr, A.; Häring, A.M.; Dabbert, S. The Environmental Impacts of Organic Farming in Europe; Institut für Landwirtschaftliche Betriebslehre, Universität Hohenheim: Stuttgart-Hohenheim, Germany, 2000; ISBN 978-3-933403-05-6.

52. Niggli, U. Organic agriculture: A productive means of low-carbon and high biodiversity food production. In Trade and Environment Review-Promoting Poles of Clean Growth to Foster the Transition to a More Sustainable Economy; United Nations Switzerland.Conference on Trade and Development (UNCTAD): Geneva, Switzerland, 2010; pp. 112-118.

53. Neugschwandtner, R.W.; Bernhuber, A.; Kammlander, S.; Wagentristl, H.; Klimek-Kopyra, A.; Lošák, T.; Zholamanov, K.K.; Kaul, H.-P. Nitrogen Yields and Biological Nitrogen Fixation of Winter Grain Legumes. Agronomy 2021, 11, 681. [CrossRef]

54. Pandey, A.; Li, F.; Askegaard, M.; Olesen, J.E. Biological Nitrogen Fixation in Three Long-Term Organic and Conventional Arable Crop Rotation Experiments in Denmark. Eur. J. Agron. 2017, 90, 87-95. [CrossRef]

55. Neugschwandtner, R.W.; Kaul, H.-P.; Moitzi, G.; Klimek-Kopyra, A.; Lošák, T.; Wagentristl, H. A Low Nitrogen Fertiliser Rate in Oat-Pea Intercrops Does Not Impair $\mathrm{N}_{2}$ Fixation. Acta Agric. Scand. Sect. B-Soil Plant Sci. 2021, 71, 182-190. [CrossRef]

56. Rigby, D.; Cáceres, D. Organic Farming and the Sustainability of Agricultural Systems. Agric. Syst. 2001, 68, 21-40. [CrossRef] 
57. Moudrý, J.; Bernas, J.; Moudrý, J.; Konvalina, P.; Ujj, A.; Manolov, I.; Stoeva, A.; Rembialkowska, E.; Stalenga, J.; Toncea, I.; et al. Agroecology Development in Eastern Europe-Cases in Czech Republic, Bulgaria, Hungary, Poland, Romania, and Slovakia. Sustainability 2018, 10, 1311. [CrossRef]

58. Zagata, L.; Hrabák, J.; Lošt'ák, M. Post-Socialist Transition as a Driving Force of the Sustainable Agriculture: A Case Study from the Czech Republic. Agroecol. Sustain. Food Syst. 2020, 44, 238-257. [CrossRef]

59. Tuomisto, H.L.; Hodge, I.D.; Riordan, P.; Macdonald, D.W. Does Organic Farming Reduce Environmental Impacts? A MetaAnalysis of European Research. J. Environ. Manag. 2012, 112, 309-320. [CrossRef] [PubMed]

60. Charles, R.; Jolliet, O.; Gaillard, G.; Pellet, D. Environmental Analysis of Intensity Level in Wheat Crop Production Using Life Cycle Assessment. Agric. Ecosyst. Environ. 2006, 113, 216-225. [CrossRef]

61. Nedbal, V.; Duffková, R.; Brom, J. Water quality protection by spectral determination of precise doses of fertilizers on arable land. In Proceedings of the 20th International Multidisciplinary Scientific GeoConference (SGEM), Albena, Bulgaria, 28 June-6 July 2019; Volume 19, pp. 317-324. Available online: https:/ / doi.org/10.5593/sgem2019V/1.4/S02.039 (accessed on 15 October 2021).

62. Knudsen, M.T.; Halberg, N.; Olesen, J.E.; Byrne, J.; Iyer, V.; Toly, N. Global trends in agriculture and food systems. In Global Development of Organic Agriculture: Challenges and Prospects; Halberg, N., Alrøe, H.F., Knudsen, M.T., Kristensen, E.S., Eds.; CABI: Wallingford, UK, 2006; pp. 1-48. ISBN 978-1-84593-078-3.

63. Coley, D.; Howard, M.; Winter, M. Local Food, Food Miles and Carbon Emissions: A Comparison of Farm Shop and Mass Distribution Approaches. Food Policy 2009, 34, 150-155. [CrossRef]

64. Birkved, M.; Hauschild, M.Z. Pest LCI-A Model for Estimating Field Emissions of Pesticides in Agricultural LCA. Ecol. Model. 2006, 198, 433-451. [CrossRef]

65. Gavrilescu, M. Fate of Pesticides in the Environment and Its Bioremediation. Eng. Life Sci. 2005, 5, 497-526. [CrossRef]

66. Kadlikova, K.; Vaclavikova, M.; Halesova, T.; Kamler, M.; Markovic, M.; Erban, T. The Investigation of Honey Bee Pesticide Poisoning Incidents in Czechia. Chemosphere 2021, 263, 128056. [CrossRef]

67. Andr, J.; Kočárek, M.; Jursík, M.; Fendrychová, V.; Tichý, L. Effect of Adjuvants on the Dissipation, Efficacy and Selectivity of Three Different Pre-Emergent Sunflower Herbicides. Plant Soil Environ. 2017, 63, 409-415. [CrossRef]

68. Stejskalová, M.; Konradyová, V.; Suchanová, M.; Kazda, J. Is Pollinator Visitation of Helianthus Annuus (Sunflower) Influenced by Cultivar or Pesticide Treatment? Crop. Prot. 2018, 114, 83-89. [CrossRef]

69. Veselá, T.; Nedbal, V.; Brom, J. Detection of pesticide in a small agricultural basin after 15 years of application ban. In Proceedings of the 20th International Multidisciplinary Scientific GeoConference SGEM, Albena, Bulgaria, 18-24 August 2020; Volume 20, pp. 75-82. [CrossRef]

70. Rehman, M.; Fahad, S.; Du, G.; Cheng, X.; Yang, Y.; Tang, K.; Liu, L.; Liu, F.-H.; Deng, G. Evaluation of Hemp (Cannabis Sativa, L.) as an Industrial Crop: A Review. Environ. Sci. Pollut. Res. 2021, 28, 52832-52843. [CrossRef] [PubMed]

71. Żuk-Gołaszewska, K.; Gołaszewski, J. Hemp production. Sustain. Agric. Rev. 2020, 42, 1-36.

72. Halvorson, A.D.; Wienhold, B.J.; Black, A.L. Tillage, nitrogen, and cropping system effects on soil carbon sequestration. Soil Sci. Soc. Am. J. 2002, 66, 906.

73. MZE. Eroze od roku 2019-Uživatelská Příručka; Ministerstvo Zemědělství České Republiky: Prague, Czech Republic, $2019 ;$ p. 52.

74. Dingha, B.; Sandler, L.; Bhowmik, A.; Akotsen-Mensah, C.; Jackai, L.; Gibson, K.; Turco, R. Industrial Hemp Knowledge and Interest among North Carolina Organic Farmers in the United States. Sustainability 2019, 11, 2691. [CrossRef]

75. Finnan, J.; Styles, D. Hemp: A More Sustainable Annual Energy Crop for Climate and Energy Policy. Energy Policy 2013, 58, 152-162. [CrossRef] 